\title{
POTENSI KOLAGEN TERIPANG EMAS SEBAGAI INHIBITOR TIROSINASE
}

\author{
Mega Safithri ${ }^{1,3^{*}}$, Iriani Setyaningsih ${ }^{2,3}$, Kustiariyah Tarman ${ }^{2,3}$, Pipih Suptijah $^{2,3}$, \\ Vitriyanna Mutiara Yuhendri ${ }^{1}$, Meydia $^{3}$ \\ ${ }^{1}$ Departemen Biokimia, Fakultas Matematika dan Ilmu Pengetahuan Alam, \\ ${ }^{2}$ Departemen Teknologi Hasil Perairan, Fakultas Perikanan dan Ilmu Kelautan, \\ ${ }^{3}$ Divisi Bioteknologi Kelautan, Pusat Kajian Sumberdaya Pesisir dan Lautan, \\ Institut Pertanian Bogor \\ Gedung Fakultas Peternakan, Jalan Agatis Wing 5 Level 5, Kampus Institut Pertanian Bogor Darmaga, \\ Bogor 16680 Jawa Barat Telepon (0251) 8423267 \\ *Korespondensi: rini_abrar@yahoo.com \\ Diterima: 2 Mei 2018/ Disetujui: 15 Agustus 2018
}

Cara sitasi: Safithri M, Setyaningsih I, Tarman K, Suptijah P, Yuhendri VM, Meydia. 2018. Potensi kolagen teripang emas sebagai inhibitor tirosinase. Jurnal Pengolahan Hasil Perairan Indonesia. 21(2): 295-303.

\begin{abstract}
Abstrak
Kolagen memiliki aktivitas antioksidan dan mampu menghambat aktivitas tirosinase pada proses melanogenesis, salah satu biota laut yang dapat dijadikan sumber kolagen alternatif adalah teripang. Penelitian ini bertujuan menentukan karakteristik kolagen dan aktivitas penghambatan enzim tirosinase oleh kolagen teripang emas (Stichopus hermanii). Penghilangan protein non kolagen dilakukan dengan cara perendaman daging teripang menggunakan $\mathrm{NaOH} 0,1 \mathrm{M}$ selama 48 jam. Isolasi kolagen dilakukan menggunakan asam asetat $0,5 \mathrm{M}$ selama $48 \mathrm{jam}$. Analisis gugus fungsi kolagen dilakukan menggunakan FTIR dan analisis aktivitas tirosinase dilakukan menggunakan spektrofotometer. Kadar protein non kolagen yang diperoleh yaitu $0,090 \mathrm{mg} / \mathrm{mL}$ dan kolagen teripang emas memiliki rendemen $0,66 \%$, nilai pH 6,91; gugus fungsi khas amida A $\left(3379,29 \mathrm{~cm}^{-1}\right)$, amida B $\left(2924,09 \mathrm{~cm}^{-1}\right)$, amida I $\left(1681,93 \mathrm{~cm}^{-1}\right)$, amida II $\left(1568,13 \mathrm{~cm}^{-1}\right)$, dan amida III $\left(1269,16 \mathrm{~cm}^{-1}\right)$. Aktivitas penghambatan tirosinase menunjukkan bahwa kolagen teripang emas memiliki nilai $\mathrm{IC}_{50} 5610 \mathrm{ppm}$. Kolagen teripang emas belum mampu menghambat aktivitas tirosinase.
\end{abstract}

Kata kunci: asam amino, FTIR, protein non kolagen

\section{The potency of Stichopus hermanii Collagen as Tyrosinase Inhibitor}

\begin{abstract}
Collagen has antioxidant activity and it is able to inhibit tyrosinase activity in the process of melanogenesis. One of the marine biotas that can be used as an alternative collagen source is sea cucumber. This study aimed to determine the activity of enzyme inhibition of tyrosinase by Stichopus hermanii collagen. Non collagen protein removal was done by soaking sea cucumber using $0.1 \mathrm{M} \mathrm{NaOH}$ for 48 hours. Collagen isolation was carried out using $0.5 \mathrm{M}$ acetic acid for 48 hours. Collagen functional group analysis was carried out using FTIR and tyrosinase activity analysis was carried out using a spectrophotometer. Non collagen protein content obtained by $0.090 \mathrm{mg} / \mathrm{mL}$ and collagen of $S$. hermanii had a yield of $0.66 \%$, $\mathrm{pH}$ value of 6.91; a typical functional group of amide A $\left(3379.29 \mathrm{~cm}^{-1}\right)$, amide B $\left(2924.09 \mathrm{~cm}^{-1}\right)$, amide I $\left(1681.93 \mathrm{~cm}^{-1}\right)$, amide II $\left(1568.13 \mathrm{~cm}^{-1}\right)$, and amide III $\left(1269.16 \mathrm{~cm}^{-1}\right)$. Tyrosinase inhibitory activity showed that $S$. hermanii had an IC50 value of $5610 \mathrm{ppm}$. S. hermanii had not been able to inhibit tyrosinase activity.
\end{abstract}

Keywords: amino acid, FTIR, non-collagen protein 


\section{PENDAHULUAN}

Kolagen merupakan protein struktural yang banyak terdapat pada semua hewan. Kolagen adalah protein fibrosa dan merupakan komponen utama jaringan ikat yang dijumpai di tulang, tendon, kulit, pembuluh darah, dan kornea mata (Marks et al. 2014). Jumlah kolagen pada manusia mencapai sepertiga dari protein total, dan menyumbang tiga perempat dari berat kering kulit. Kerusakan kolagen, selain karena terpapar oleh radiasi UV dari sinar matahari, kandungan kolagen pada tubuh manusia juga berkurang seiring dengan bertambahnya usia (Draelos dan Thaman 2006). Kerusakan dan penurunan jumlah kolagen terjadi karena faktor usia diatasi dengan penambahan kolagen dalam formulasi kosmetik. Penambahan kolagen ini didasarkan pada sifat kolagen yang dapat mengontrol penguapan cairan, menjaga fleksibelitas, mambantu pengembangan jaringan granulasi, melindungi dari efek radiasi UV, serta sebagai perlindungan dari serangan fisik dan bakteri (Khan dan Khan 2013).

Paparan sinar UV dalam jangka waktu yang lama dapat menyebabkan gangguan pada kulit, salah satunya meningkatkan sintesis melanin yang menimbulkan hiperpigmentasi. Hiperpigmentasi merupakan sintesis melanin yang berlebih. Melanin merupakan pigmen yang terdapat pada kulit manusia. Melanin yang disintesis secara normal dapat melindungi kulit dari bahaya UV, namun sintesis melanin yang abnormal menghasilkan malesma atau bintik-bintik berwarna coklat dan bentuk lain dari hiperpigmentasi. Hiperpigmentasi melanin dapat menjadi masalah estetika, serta kesehatan pada kulit (Jenifer et al. 2012). Tirosinase merupakan enzim utama dalam sintesis melanin. Paparan sinar UV dalam waktu lama dapat meningkatkan aktivitas enzim tirosinase, sehingga meningkatkan sintesis melanin. Enzim tirosinase terlibat dalam dua rekasi penting dalam sintesis melanin, yaitu oksidasi tirosin menjadi L-DOPA, dan oksidasi L-DOPA menjadi DOPAquinon (Zaidi et al. 2014), sehingga untuk mengurangi sintesis melanin yang berlebih diperlukan senyawa yang dapat menghambat kerja enzim tirosinase, salah satunya adalah kolagen (Zhuang et al. 2009 ${ }^{\mathrm{b}}$ ).
Kolagen yang banyak beredar dipasaran umumnya berasal dari sapi atau babi. Kolagen juga dapat diperoleh dari bahan baku hasil perairan di antaranya dari kulit ikan gabus dan ikan patin (Wibawa 2015; Wulandari 2016; Hardyanti 2014), serta teripang. Siahaan et al. (2017) menyatakan bahwa teripang mengandung kolagen yang tinggi. Tubuh teripang mengandung $70 \%$ protein kolagen. Teripang merupakan komponen penting dalam ekosistem laut yang tersebar di lautan seluruh dunia. Jumlah spesies teripang yang ada saat ini adalah sekitar 125 spesies (Bordbar et al. 2011). Perairan Indonesia memiliki 53 jenis teripang yang meliputi genus Holothuria, Actinopyga, Bohadschia, Labiodemas, Thelonata dan Stichopus. Jenis-jenis teripang banyak diperdagangkan di internasional terdapat $29 \mathrm{jenis,} \mathrm{diantaranya} \mathrm{yang} \mathrm{termasuk} \mathrm{ke}$ dalam famili Holothuridae dan Stichopodidae (Pankey et al. 2014). Ekstraksi kolagen teripang sudah pernah dilakukan oleh Alhana et al. (2015) menggunakan teripang gamma namun hanya sampai pada tahap karakterisasi. Aktivitas penghambatan enzim tirosinase oleh kolagen telah dilakukan oleh Zhuang et al. (2009) menggunakan kolagen dari ubur-ubur sebesar $5 \mathrm{mg} /$ $\mathrm{mL}$ pada konsentrasi 47,2\%, sedangkan Abdillah et al. (2017) yang menganalisis $\mathrm{IC}_{50}$ anti-tirosinase kolagen dari teripang jenis Holothurialeucospilota $1,20 \mathrm{mg} / \mathrm{mL}$. Penelitian ini bertujuan menentukan karakteristik kolagen dan aktivitas penghambatan enzim tirosinase oleh kolagen dari daging teripang jenis emas (Stichopus hemanni).

\section{BAHAN DAN METODE Bahan dan Alat}

Bahan utama yang digunakan adalah teripang emas (Stichopus hermanni) yang berasal dari Labuan Bajo, Nusa Tenggara Timur. Teripang dibersihkan lalu disimpan di freezer sampai beku. Sampel yang sudah beku kemudian dimasukkan coolbox (stereofoam) dan diberi es untuk dikirimdikirim melalui jasa argodan diterima di Laboratorium dalam keadaan beku. Bahan yang digunakan terdiri dari akuades, DMSO (Merck), $\mathrm{NaH}_{2} \mathrm{PO}_{4}$ (Merck), $\mathrm{Na}_{2} \mathrm{HPO}_{4}$ (Merck), asam kojat (sigma aldrich), enzim tirosinase 
(333 U/mL dalam buffer fosfat) (sigma aldrich), dan substrat (L-DOPA $2 \mathrm{mM}$ ) (sigma Aldrich). Alat-alat yang digunakan Fourier Transform Infrared (FTIR) (spectrum one Perkin Elmer), spektrofotometer (Genesys 10 $\mathrm{uV}$ Thermo Scientific), dan microplate reader (Epoch bi0Tek. Gen51.10)

\section{Metode Penelitian \\ Preparasi daging teripang segar}

Preparasi mengacu pada Karnila et al. (2011) dengan membersihkan teripang dari kotoran yang menempel pada kulit. Sampel selanjutnya dibelah dan dipisahkan daging dengan bagian tubuh teripang lainnya yaitu kulit, jeroan, dan gonad.

\section{Ekstraksi kolagen dari daging teripang emas}

Pra-perlakuan daging teripang segar mengacu pada Alhana et al. (2015) dengan modifikasi. Pra-perlakuan dilakukan dengan merendam daging teripang menggunakan larutan $\mathrm{NaOH} \mathrm{0,1} \mathrm{M} \mathrm{untuk} \mathrm{menghilangkan}$ protein nonkolagen, lemak, mineral, dan pigmen yang ada pada daging teripang. Perendaman daging teripang dilakukan dalam larutan $\mathrm{NaOH}$ 0,1 $\mathrm{M}$ dengan rasio daging dan larutan $\mathrm{NaOH}$ 1:10 (b/v). Larutan perendaman diganti setiap 6 jam dan larutan sisa perendaman diuji kandungan protein dengan metode Bradford. Daging hasil praperlakuan dicuci dengan akuades sampai mencapai pH 7.

Hidrolisis kolagen larut asam (Modifikasi Erizal et al. 2012). Ekstraksi kolagen dari daging teripang emas dilakukan dengan metode larut asam. Serat kolagen kasar yang diperoleh dari pra perlakuan direndam dengan $\mathrm{CH}_{3} \mathrm{COOH} 0,5 \mathrm{M}$ pada suhu $4^{\circ} \mathrm{C}$ selama 48 jam. Proses selanjutnya disaring dengan kain blacu, kemudian filtrat dikeringkan menggunakan pengering beku sehingga diperoleh kolagen kering.

\section{Prosedur Analisis}

Analisis rendemen kolagen

Nilai rendemen kolagen diperoleh dari perbandingan berat kering kolagen yang dihasilkan dengan berat bahan daging teripang emas (AOAC 2005). Nilai rendemen diperoleh dengan rumus:

Rendemen kolagen $(\%)=\frac{\text { Berat kering kolagen }}{\text { Berat bahan baku }} \times 100 \%$

Analisis kadar protein

Analisis kandungan protein (nonkolagen) pada $\mathrm{NaOH}$ sisa perendaman daging teripang dilakukan menggunakan metode Bradford (1976) dengan bovine serum albumin (BSA) sebagai standar. Sampel dimasukkan ke dalam tabung reaksi sebanyak $50 \mu \mathrm{L}$, kemudian ditambahkan reagen Bradford sebanyak 2,5 $\mathrm{mL}$. Proses selanjutnya diinkubasi selama 5 menit, kemudian diukur absorbansinya dengan spektrofotometer pada panjang gelombang $610 \mathrm{~nm}$. Konsentrasi standar BSA yang digunakan adalah $0 ; 400 ; 500 ; 600 ; 800$; 1.000 dan 1.200 ppm.

\section{Karakterisasi kolagen}

Analisis gugus fungsi dengan FTIR dilakukan untuk mengetahui gugus fungsi khas yang ada pada kolagen yang dihasilkan. Kolagen sebanyak 0,02 g dihaluskan dengan 100 mg Kalium Bromida dalam mortar hingga homogen, kemudian dipadatkan ke dalam cetakan pelet serta divakum dalam mesin pencetak pelet. Pengukuran sampel uji dilakukan pada bilangan gelombang 4000-500 $\mathrm{cm}^{-1}$. Spektra FTIR yang dihasilkan menunjukkan puncak-puncak serapan bilangan gelombang dari sampel uji. Gugus-gugus fungsi sampel uji ditentukan berdasarkan puncak serapan bilangan gelombang yang terdeteksi dengan wilayah serapan untuk gugus fungsi protein.

Analisis $\mathrm{pH}$ kolagen mengacu pada Alhana et al. (2015). Kolagen sebanyak $1 \mathrm{~g}$ dilarutkan dalam $20 \mathrm{~mL}$ akuades, ditambahkan $50 \mathrm{~mL}$ akuades, dan dihomogenkan. Alat $\mathrm{pH}$ meter dinyalakan dan dibiarkan hingga stabil. Elektroda dicelupkan ke dalam sampel beberapa saat sampai diperoleh nilai $\mathrm{pH}$ yang stabil. Pengukuran dilakukan sebanyak 3 kali.

\section{Uji inhibisi tirosinase}

Uji inhibitor tirosinase mengacu pada Batubara et al. (2010). Sampel kolagen hasil ekstraksi dilarutkan dalam DMSO hingga konsentrasinya $64.000 \mathrm{ppm}$. Larutan stok 
disiapkan dengan melarutkan sampel ke dalam bufer fosfat $50 \mathrm{mM}$ (pH 6,5). Sampel sebanyak $70 \mu \mathrm{L}$ diuji dengan konsentarsi 100 ; $200 ; 400 ; 1.600 ; 3.200 ; 6.400 ; 9.600$ dan 12.800 ppm. Asam kojat $70 \mu \mathrm{L}$ sebagai kontrol positif diuji pada konsentrasi 200 ppm ditambahkan $30 \mu \mathrm{L}$ enzim tironase (sigma 333 unit $/ \mathrm{mL}$ dalam bufer fosfat). Substrat (L-DOPA 2 $\mathrm{mM}$ ) sebanyak $110 \mu \mathrm{L}$ ditambahkan dan campurannya diinkubasi pada suhu ruang selama 30 menit. Larutan pada masingmasing sumur diukur nilai absorbansinya dengan menggunakkan microplate reader pada panjang gelombang $492 \mathrm{~nm}$ untuk menentukan persen inhibisi dan nilai konsentrasi hambat 50\% $\left(\mathrm{IC}_{50}\right)$. Persentase inhibisi dihitung dengan membandingkan absorbansi tanpa penambahan sampel (A) dengan penambahan sampel (B) pada panjang gelombang $492 \mathrm{~nm}$. Persentase inhibisi dapat dihitung dengan persamaaan:

$$
\text { Inhibisi (\%) }=\frac{A-B}{A} \times 100 \%
$$

Analisis asam amino

Analisis asam amino dilakukan menggunakan High performance Liquid Chromatography (HPLC) (AOAC 2005). Metode ini diawali dengan hidrolisis sampel melalui penambatan $\mathrm{HCl} 6 \mathrm{~N}$ dan pemanasan, hemudian hidrolisat dikeringkan dan diderivatisasi dengan larutan phenylisothiocyanat (PITC) atau Edman's Reagent dan ditambahkan asetonitril sebagai fase gerak. Sampel diinjeksikan kedalam HPLC setelah disaring terlebih dahulu menggunakan kertas saring milipore $0,45 \mu$. Konsentrasi asam amino dihitung dengan rumus :

$$
\begin{aligned}
& \text { Konsentrasi asam amino }=\frac{\text { luas area sampel } \times \mathrm{C} \times \mathrm{FP} \times \mathrm{BM} \times 1 \mathrm{OO}}{\text { luas area sandar } \times \text { bobot sampel }(\mathrm{g})} \\
& \mathrm{C} \quad: \text { Konsentrasi standar asam amino }(\mathrm{ug} / \mathrm{mL}) \\
& \mathrm{FP}
\end{aligned}
$$

\section{HASIL DAN PEMBAHASAN \\ Karakteristik KolagenKadar protein nonkolagen dan rendemen kolagen}

Perendaman 6 jam pertama menunjukkan kadar protein sebesar $0,348 \mathrm{mg} / \mathrm{mL}$. Kadar protein ini semakin menurun seiring dengan lamanya waktu perendaman. Perendaman pada jam ke-48 menunjukkan kadar protein sebesar 0,090 mg/mL (Gambar 1). Larutan basa yang digunakan dalam proses praperlakuan ini adalah $\mathrm{NaOH} 0,1 \mathrm{M}$. Larutan $\mathrm{NaOH} 0,05$ dan 0,1 M dapat melarutkan protein nonkolagen tanpa menyebabkan kehilangan kolagen, serta membuat daging kolagen mengembang. Menurut Jaswir et al. (2011) selama perendaman dalam $\mathrm{NaOH}$, sampel semakin mengembang karena adanya gaya elektrostatik sehingga memudahkan masuknya air dan menyebabkan

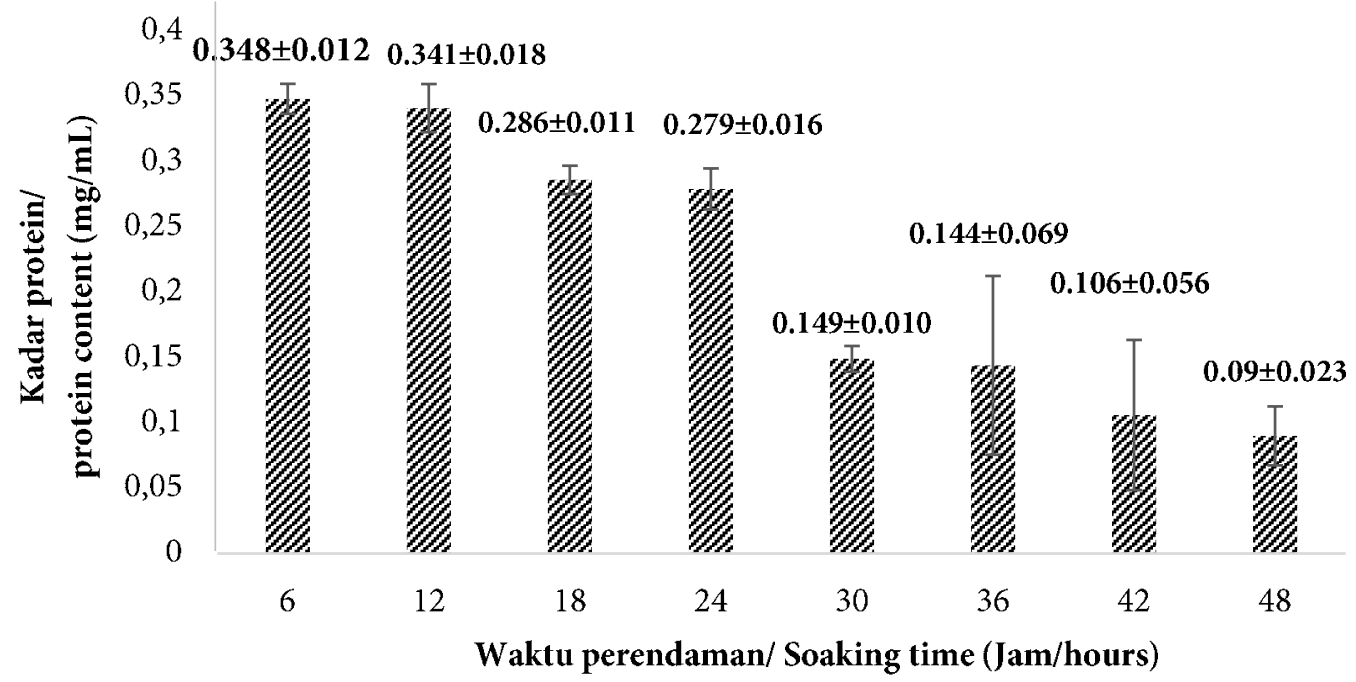

Gambar 1 Kadar protein nonkolagen

(Figure 1 Non-collagen protein content) 
protein nonkolagen serta molekul selain protein yang terjebak dalam matriks kolagen menjadi mudah dilepaskan.

Rerata rendemen kolagen teripang emas yang diperoleh adalah $0,66 \pm 0,14 \%$. Faktor yang memengaruhi nilai rendemen yaitu perbedaan metode ekstraksi, lama waktu ekstraksi, perbandingan sampel dan pelarut, konsentrasi asam basa, dan jenis bahan baku yang digunakan (Diantika et al. 2014; Potaros et al. 2009).

\section{Nilai pH kolagen}

Nilai $\mathrm{pH}$ kolagen teripang emas yang dihasilkan adalah 6,91 $\pm 0,0125$. Nilai $\mathrm{pH}$ kolagen yang dihasilkan dipengaruhi oleh konsentrasi asam yang digunakan. Nilai $\mathrm{pH}$ kolagen yang dihasilkan lebih rendah dari penelitian Alhana et al. (2015) yaitu 7,37 yang menggunakan teripang gamma, sedangkan nilai $\mathrm{pH}$ 6,91 masih sesuai nilai BSN yaitu nilai pH kolagen berkisar 6,5-8 (BSN 2014).

\section{Gugus fungsi kolagen}

Hasil spektrum inframerah kolagen daging teripang emas disajikan pada Gambar 2. Kolagen yang dihasilkan menunjukkan puncak-puncak serapan pada wilayah serapan yang meliputi amida $A$, amida $B$, amida I, amida II, dan amida III. Puncak puncak serapan ini merupakan serapan khas yang ada pada kolagen.
Wilayah serapan standar kolagen dan hasil pengukuran kolagen teripang emas serta karakteristik gugus fungsi kolagen hasil isolasi dapat dilihat pada Tabel 1. Amida A teridentifikasi bilangan gelombang 3379,29; amida B 2924,09; amida I 1681,93; amida II 1568,13; dan amida III $1269,16 \mathrm{~cm}^{-1}$. Amida I memiliki struktur sekunder protein antara lain $\alpha$-helix, $\beta$-sheet, $\beta$-turn, dan random coil (loop). Gugus fungsi amida III mengkonfirmasi struktur tripel heliks kolagen teripang emas yang ditunjukkan dengan nilai rasio intensitas amida III dan intensitas pada bilangan gelombang $1450 \mathrm{~cm}^{-1}$ kolagen mendekati 1 yaitu sebesar 1.34. Menurut Nikoo et al. (2011), kolagen yang terdenaturasi menjadi gelatin memiliki intensitas rasio 0,59. Penggunaan asam akan meningkatkan $\mathrm{H}^{+}$ sehingga air lebih mudah masuk kedalam serat kolagen dan terbentuknya ikatan hidrogen antara gugus nonpolar pada kolagen dengan $\mathrm{H}^{+}$dari asam, hal tersebut dapat mendukung rusaknya struktur serat kolagen melalui terganggunya ikatan nonkovalen dan memudahkan melarutkan kolagen (Jaswir et al. 2011).

\section{Aktivitas Inhibisi Enzim Tirosinase}

Enzim tirosinase mangkatalisis dua rekasi penting dalam sintesis melanin, yaitu oksidasi tirosin menjadi L-DOPA, dan oksidasi L-DOPA menjadi DOPAquinon, yang

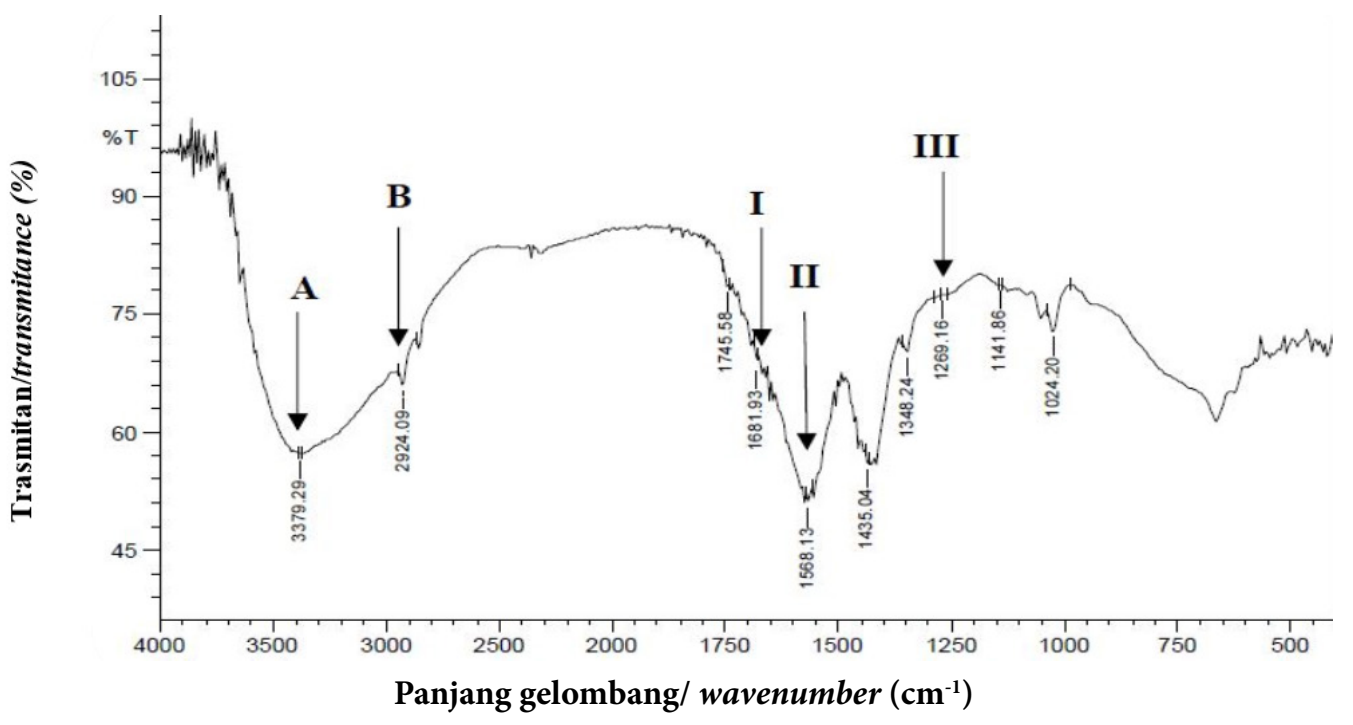

Gambar 2 Spektrum FTIR kolagen teripang emas (Figure 2 Stichopus hermanii collagen FTIR spectrum) 
Tabel 1 Karakteristik gugus fungsi kolagen

(Table 1 Characteristics of collagen functional groups)

\begin{tabular}{ccccc}
\hline \multirow{2}{*}{$\begin{array}{c}\text { Jenis amida/ } \\
\text { Amide type }\end{array}$} & \multicolumn{2}{c}{ Bilangan gelombang puncak serapan $\left(\mathrm{cm}^{-1}\right)$} & Karakteristik \\
\cline { 2 - 4 } & $\begin{array}{c}\text { Standar wilayah } \\
\text { serapan/ } \\
\text { Absorption area } \\
\text { standards }\end{array}$ & $\begin{array}{c}\text { Serapan yang } \\
\text { diperoleh/ } \\
\text { Absorption } \\
\text { obtained }\end{array}$ & $\begin{array}{c}\text { Serapan kolagen } \\
\text { standar/ Standard } \\
\text { collagen uptake }\end{array}$ & $\begin{array}{c}\text { Characteristics of } \\
\text { amide }\end{array}$ \\
\hline Amide A & $3350-3550^{1}$ & 3379.29 & 3332.29 & $\mathrm{NH}$ stretching \\
Amide B & $2935-2915^{2}$ & 2924.09 & 2924.09 & $\begin{array}{c}\mathrm{CH} \text { asimetri } \\
\text { stertching }\end{array}$ \\
Amide I & $1600-1700^{3}$ & 1681.93 & 1647.21 & $\mathrm{C}=\mathrm{O}$ stetching \\
Amide II & $1480-1575^{3}$ & 1568.13 & 1546.91 & $\begin{array}{c}\mathrm{NH} \text { bending, } \\
\text { CN stetching }\end{array}$ \\
Amide III & $1229-1301^{3}$ & 1269.16 & 1334.74 & $\begin{array}{c}\text { NH bending, } \\
\text { CN stetching }\end{array}$ \\
\hline
\end{tabular}

Keterangan: ${ }^{1}$ Erizal et al. (2012); ${ }^{2}$ Coates (2000); ${ }^{3}$ Kong dan Yu (2007)

selanjutnya diubah menjadi pigmen melanin melalui proses nonenzimatik(Zaidi et al.2014). Hasil persentase daya inhibisi enzim tirosinase disajikan pada Gambar 3. Nilai penghambatan tertinggi yaitu pada konsentrasi $12.800 \mathrm{ppm}$ sebesar $83,713 \%$, persentase inhibisi ini lebih rendah dibandingkan dengan asam kojat 200 ppm (94,263\%). Zhuang dan Liping (2012) melaporkan bahwa kolagen dari ubur-ubur pada konsentrasi 100 ppm dapat menghambat aktivitas enzim tirosinase 40,4\%, sedangkan kolagen teripang emas pada konsentrasi 100 ppm menghambat aktivitas enzim tirosinase $10,085 \%$. Kolagen teripang emas diuji nilai $\mathrm{IC}_{50}$. Hasil penelitian $\mathrm{IC}_{50}$ enzim tirosinase menunjukkan bahwa kolagen teripang emas memiliki nilai $\mathrm{IC}_{50} 5.610 \mathrm{ppm}$. Nilai $\mathrm{IC}_{50}$ ini lebih tinggi dibandingkan penelitian Abdillah et al. (2017) yang memperoleh $\mathrm{IC}_{50} 1.200 \mathrm{ppm}$ menggunakkan kolagen dari teripang jenis Holothuria leucospilota. Nilai IC $_{50}$ semakin rendah maka semakin baik aktivitas penghambatan enzim dari sampel hasil pengujian (Filbert et al. 2014). Sari et al. (2015) menggolongkan sampel dikatakan inhibitor aktif jika memiliki nilai $\mathrm{IC}_{50}$ kurang dari $1.000 \mathrm{ppm}$, sedangkan $\mathrm{IC}_{50} \mathrm{di}$ atas $1.000 \mathrm{ppm}$ maka sampel tersebut tergolong inhibitor tidak aktif, dengan demikian kolagen teripang emas pada penelitian ini tergolong inhibitor tirosinase yang tidak aktif. Zhuang dan Liping (2012) menyatakan, perbedaan nilai $\mathrm{IC}_{50}$ dapat dipengaruhi oleh komposisi asam amino. Peptida yang mengandung total hydrophobic amino acids (THAA) yang tinggi memiliki aktivitas antioksidan yang tinggi untuk menekan reaksi oksidatif, sehingga dapat menurunkan aktivitas enzim tirosinase (Zhuang dan Liping 2012).

\section{Kadar Asam Amino}

Pengukuran kadar asam amino menggunakan alat Ultra Performance Liquid Chromatography (UPLC). Analisis asam amino yang dilakukan adalah pengukuran kadar 15 asam amino. Asam amino yang diukur adalah histidina, treonina, prolina, tirosina, leusina, asam aspartat, lisina, glisina, arginina, alanina, valina, isoleusina, fenilalanina, asam glutamat dan serina (Tabel 2). Hasil ini menunjukkan bahwa kolagen teripang emas memiliki asam amino hidrofobik yang tinggi, sehingga dapat menurunkan aktivitas enzim tirosinase (Zhuang dan Liping 2012). Penggunaan asam asetat meningkatkan $\mathrm{H}^{+}$pada tahap isolasi, menyebabkan air lebih mudah masuk ke dalam serat kolagen dan terbentuknya ikatan hidrogen antara gugus nonpolar asam amino hidrofobik pada kolagen dengan $\mathrm{H}^{+}$dari asam, hal tersebut dapat mendukung rusaknya struktur serat kolagen melalui terganggunya ikatan nonkovalen dan memudahkan melarutkan kolagen (Jaswir et al. 2011), sehingga dapat menurunkan aktivitas enzim tirosinase. 
Tabel 2 Kadar asam amino kolagen

(Table 2 Amino acid of collagen)

\begin{tabular}{cc}
\hline & Kadar asam amino/ content of amino acid (\%) \\
\hline Asam amino/amino acid & Asam amino hidrofobik \\
\hline Isoleusina & $2.41 \pm 0.04$ \\
Leusina & $4.49 \pm 0.05$ \\
Fenilalanina & $3.18 \pm 0.03$ \\
Alanina & $8.07 \pm 0.00$ \\
Glisina & $21.81 \pm 0.00$ \\
Tirosina & $3.14 \pm 0.04$ \\
Valina & $3.05 \pm 0.03$ \\
\hline Sub total & 46.15 \\
\hline & Asam amino hidrofilik \\
\hline Arginina & $9.97 \pm 0.04$ \\
Histidina & $1.74 \pm 0.00$ \\
Treonina & $6.67 \pm 0.11$ \\
Asam Aspartat & $7.17 \pm 0.02$ \\
Asam Glutamat & $12.65 \pm 0.04$ \\
Lisina & $0.71 \pm 0.01$ \\
Prolina & $8.84 \pm 0.01$ \\
Serina & $6.60 \pm 0.02$ \\
\hline Sub Total & 54.35 \\
\hline Total & 100.00 \\
\hline
\end{tabular}

\section{KESIMPULAN}

Kolagen berhasil diisolasi dari daging teripang emas memiliki rendemen 0,66\%, nilai $\mathrm{pH}$ 6,91. Kolagen teripang emas memiliki gugus fungsi khas pada amida $\mathrm{A}$, amida B, amida I, amida II, dan amida III dengan bilangan gelombang 3379,29; 2924,09; 1681,$93 ; 1269,16 \mathrm{~cm}^{-1}$. Kolagen teripang emas memiliki aktivitas penghambatan enzim tirosinase dengan $\mathrm{IC}_{50} 5.610 \mathrm{ppm}$. Kadar asam amino hidrofobik kolagen yaitu $15,44 \%$.

\section{DAFTAR PUSTAKA}

Abdillah S, Wijayanti G, Setiawan M, Noor US, Nurilmala M. 2017. In vitro anti-tyrosinase and anti-elastase activity of collagen from sea cucumber (Holothuria leucospilota). African Journal of Biotechnology. 16(1): 771-776.

Alhana, Suptijah P, Tarman K. 2015. Ekstraksi dan karakterisasi kolagen dari daging teripang gamma. Jurnal Pengolahan Hasil Perikanan Indonesia. 18(2): 150-161.
[AOAC] Association of Official Analytical Chemyst. 2005. Official Method of Analysis of The Association of Official Analytical of Chemist. Arlington Virginia (US): Published by The Association of Official Analytical Chemist, Inc.

Batubara I, Darusman LK, Mitsunaga T, Rahminiwati M, Djauhari E. 2010. Potency of Indonesia medicinal plants as tyrosinase inhibitor and antioxidant agent. Journal of Biological Sciences. 10:138-144.

Bordbar S, Anwar F, Saari N. 2011. Hight value components and bioactives from sea cucumbers for functional foods-A Review. Merine Drugs. 1761-1805.

Bradford M. 1976. Rapid and sensitive method for the quantitation of microgram quantities of protein utilizing the principle dye binding. Analytical of Biochemistry. 72: 248-254.

[BSN] Badan Standardisasi Nasional. 2014. Kolagen kasar dari sisik ikan-Syarat mutu 
dan pengolahan: SNI 8076-2014. Jakarta (ID): Badan Standardisasi Nasional.

Coates J. 2000. Interpreration of infrared spectra, a practical approach. Di dalam: Meyers RA, editor. Encyclopedia of Analytical Chemistry. USA (US): John Wiley \& Sons Ltd.

Diantika F, Sutan SM, Yulianingsih R. 2014. Pengaruh ekstraksi dan konsentrasi pelarut etanol terhadap ekstraksi antioksidan biji kakao (Theobroma cacao L.). Jurnal Teknologi Pertanian. 15(3): 159-164.

Draelos ZD, Thaman LA. 2006. Cosmetic Science and Technology Series. Volume ke-30, Cosmetic Formulation of Skin Care Products. New York (US): Taylor \& Francis Group.

Erizal, Abbas B, Setyo AK, Sulistiono GS, Sudirman. 2012. Pengaruh iradiasi gamma pada sifat fisiko-kimia kolagen dalam larutan. Jurnal Sains Materi Indonesia. 15(4): 221-225.

Filbert, Koleangan HSJ, Runtuwenw MRJ, KamuVS. 2014. Penentuan aktivitas antioksidan berdasarkan nilai $\mathrm{IC}_{50}$ ekstrak metanol dan fraksi hasil partisinya pada kulit biji Pinang Yaki (Areca vestiaria Giseke). Jurnal MIPA UNSRAT. 3(2):149-154.

Hardyanti STK. 2014. Isolasi kolagen dari kulit ikan patin (Pangasius sp.). [Skripsi]. Bogor (ID): Institut Pertanian Bogor.

Jaswir I, Monsur HA, Salleh HM. 2011. Nano-structural analysis of fish collagen extracts for new process development. African Journal of Biotechnology. 10(81): 18847-18854.

Jenifer C, Stephie CM, Abhishri SB, Shalini BU. 2012. A review on skin whitening property of plant extracts. International Journal of Pharma and Bio Scicence. 3(4): 332-347.

Karnila R, Astawan M, Sukarno, Wresdiyati T. 2011. Karakteristik konsentrat protein teripang pasir (Holothuria scabra J.) dengan bahan pengekstrak aseton. Jurnal Perikanan dan Kelautan. 16(1): 90-102.

Khan R, Khan MH. 2013. Use of collagen as a biomaterial: An update. Journal of Indian Society of Periodontology. 17(4): 539-542.
Komala AH. 2015. Ekstraksidan karakterisasi kolagen dari kulit ikan tongkol (Euthynnus affinis). [Skripsi]. Bogor (ID): Insititut Pertanian Bogor.

Kong J, Yu S. 2007. Fourier transform infrared spectroscopic analysis of protein secondary structures. Acta Biochimica Biophysica Sinica. 39(8): 549-559.

Marks DB, Marks AD, Smith CM. 2014. Biokimia Kedokteran Dasar: Sebuah Pendekatan Klinis. Jakarta (ID): EGC.

Nikoo M, Xu X, Benjakul S, Xu G, RamiresSuarez JC, Ehsani A, Kasankala LM, Duan X, Abass S. 2011. Characterization of gelatin from the skin of farmed amur sturgeon Acipenser schrenckii. International Aquatic Research. 3(2): 135-145.

Pankey H, Lantu S, Manuand L, Mokolensang JF. 2014. Prospect of sea cucumber culture in Indonesia as potensial food sources. Coastal and Development. 15(2): 114-124.

Potaros T, RaksakulthaiN, Runglerdkreangkrai J, Worawattanamateekul W. 2009. Characteristics of collagen from nile tilapia (Oreochromis niloticus) skin isolated by two different methods. Kasetsart Journal-Natural Science. 43(3): 584-593.

Sari KR, Utami R, Batubara I, Carolina A, Febriany S. 2015. Aktivitas antioksidan dan inhibitor tirosinase ekstrak metanol mangium (Acacia mangium). Jurnal Ilmu dan Teknologi Kayu Tropis. 13(1): 88-97.

Siahaan EA, Pangestu R, Munandar H, Kim SK. 2017. Review cosmeceuticals properties of sea cucumbers: Prospects and Trends. Cosmetic. 4(26):1-12. Wibawa SF. 2015. Ace inhibition and antioxidant activities of collagen hydrolysate from skin of snakehead fish (Channa striata). [Skripsi]. Bogor (ID): Institut Pertanian Bogor.

Wulandari. 2016. Karakterisasi fisikokimia kolagen yang diisolasi dengan metode hidro-ekstraksi dan stabilisasi nanokolagen kulit ikan gabus (Channa striata). [Skripsi]. Bogor (ID): Institut Pertanian Bogor.

Zaidi UK, Ali SA, Ali AS, Naaz I. 2014. Review article: microbial tyrosinase: 
promising enzyme for pharmaceutical, food bioprocessing, and environmental industry. Biochemistry Research International. 1-16.

Zhuang Y, Zhao X, Li B. 2009a. Optimization of antioxidant activity by response surface methodology in hydrolysates of jellyfish (Rhopilema esculentum) umbrella collagen. Journal of Zhejiang University of Science B. 10(8): 572-579.
Zhuang Y, Sun L, Zhao X, Wang J, Hou H, Li B. 2009b. Antioxidant and melanogenesisinhibitory activities of collagen peptide from jellyfish (Rhopilema esculentum). Journal of the Science of Food and Agriculturale. 89: 1722-1727.

Zhuang Y, Liping S. 2012. Anti-melanogenic activities of collagen peptides from jellyfish (Stomolophus meleagris). Advanced Materials Research. 343: 505512. 